\title{
A FILAMENT SZÁL ÚJRAHASZNOSÍTÁSA A 3D NYOMTATÁSHOZ
}

\author{
Kmetz Barbara \\ MSc gépészmérnök hallgató, Miskolci Egyetem, Gép- és Terméktervezési Intézet \\ 3515 Miskolc, Miskolc-Egyetemváros, e-mail: kmetzbarbara@gmail.com \\ Takács Ágnes Judit \\ egyetemi docens, Miskolci Egyetem, Gép- és Terméktervezési Intézet \\ 3515 Miskolc, Miskolc-Egyetemváros, e-mail: takacs.agnes@uni-miskolc.hu
}

\begin{abstract}
Absztrakt
A tanulmány elsö fele bemutatja a 3D nyomtatás és a nyill forráskódú mozgalom rövid történetét. A szerzők ismertetik az FDM extrudálásos nyomtatási technológiát, valamint a nyomtatás felhasználási területeit. A publikáció részletes leirást ad a Creality Ender 5 nyomtatóról, valamint az ezen nyomtató által nyomtatott tárgyakról. A tanulmány második fele egy nyomtatószál újrahasznositó gép koncepcionális tervezését taglalja. A szükséges piac-és szabadalomkutatás során feltárt funkcionális részegységek variálásával számos megoldásváltozat került kidolgozásra, melyek közül az optimális megoldás értékeléssel került kiválasztásra.
\end{abstract}

Kulcsszavak: 3D nyomtatás, újrahasznositás, Creality Ender 5, filament, koncepcionális tervezés

\begin{abstract}
In the first part of the study the brief history of $3 D$ printing and the open source movement is introduced. The FDM extrusion technology is reviewed, also the areas where the technology can be used. There is a detailed description about the Creality Ender 5 printer and its printed objects. The study's next main part contains the conceptual design of a filament recycling machine. After market and patent research the functions are established. Varying them, different solutions were determined. Evaluating the variants, the optimal solution was defined.
\end{abstract}

Keywords: 3D printing, recycling, Creality Ender 5, filament, conceptual design

\section{Bevezetés}

A 3D nyomtatás napjaink népszerü additív gyártótechnológiáinak egyike. Az utóbbi két évtizedben terjedt el igazán széles körben, manapság már számos fajtája és felhasználási módja létezik. Története nem nyúlik vissza a régmúltba, csupán az 1990-es évekbe. A fizikailag megfogható tárgyak gyártása előtt háromdimenziós tervező programok valamelyikében meg kell azokat tervezni, majd a választott nyomtatási technológia szerint elindítható a nyomtatás.

A 3D nyomtatáshoz különböző speciálisan elöállított nyomtatóanyagokat kell használni. Ezek a szálak (filamentek) lehetnek fémtartalmúak, polimerek, kerámiák, kompozitok, úgynevezett okos anyagok, illetve ezek mellett olyan különleges anyagokat is lehet nyomtatni, mint az ételek, például pizzák. Ide sorolható még a textil és a beton is, továbbá ezeken kívül is lehet találkozni különleges nyomtató anyagokkal, számuk napról napra bővül. A felhasznált filamentek túlnyomó részben azonban müanyagok, ami sok környezetvédelmi kérdést vet fel. 
A 3D nyomtatás felhasználhatósága meglehetősen széleskörü, többek között a repülőgépgyártásban, az autóiparban, az építészetben, az építőiparban, az elektronikában, az orvoslásban, ezeken kívül pedig még számtalan területen hasznosítják. Mára már hobbygépek ezrei találnak otthonra az alkotni vágyó emberek barkács mühelyeiben. A hobbynyomtatók számára mind árban, mind felhasználásban a legelérhetőbb anyagok a különböző tulajdonságú polimer nyomtatószálak, amelyek közül sok komposztálható ugyan, de csak adott körülmények között, ezért van szükség filament újrahasznosító gépekre. A tanulmány során egy ilyen újrahasznosító gép koncepcionális tervezése volt a feladat. [1]

\subsection{A 3D nyomtatás mozgolódása a világban}

Valahol a 2000-es évek közepén rohamosan elkezdődött terjedni a technológia. Az SLS gépek elérhetőek lettek a közönség számára is. 2006-ban már ipari alkatrészek nyomtatására is volt igény. Nem sokkal ezután kezdtek el különböző anyagokat használni a nyomtatáshoz, ami még jobban felkeltette az iparágak érdeklődését. Egy mérnök szemszögéből nagy előre lepésnek számított, hogy sokféle lehetőség volt alkatrészek gyártására. A korszak végére a $3 \mathrm{D}$ nyomtatás piaca elérhetővé vált a közönség számára is. A MakerBot megjelenése és a nyílt forráskódú „csináld magad” nyomtatókészleteik csak még tovább fokozták a technológia népszerüségét, mivel a 3D nyomtató készlet egyszerü módja volt a technológia elsajátításának, emellett ezek a gépek már megfizethetők voltak a hobbyfelhasználók számára is. Azt lehet gondolni, hogy az előző történések után a 3D nyomtatás elérte fejlődésének a csúcspontját, azonban ez nem így van: a technológia szinte határtalan. A hobby felhasználók számára egyre elérhetőbbek lesznek a nyomtatók, mert az áruk rohamosan csökken, a nyomtatás pontossága napról napra javul, a gépek felhasználóbarátok, vagyis bárki megtanulhatja használni öket könnyedén, az ingyenes szoftverek pedig könnyen elérhetők bárki számára, nem is beszélve a 3D nyomtatással kapcsolatos honlapokról, ahova modellek millióit töltik fel a felhasználók természetesen legtöbbjüket letölthető, nyílt forráskóddal. Senki sem tudhatja, hogy ezek után merre tovább, de azt lehet sejteni, hogy még számos nagyszerü dolgot lehet majd hozzáírni a 3D nyomtatás történetéhez [3]. Az egyetlen korlát az emberi képzelőerö lesz, amely egyesek szerint határtalan:

\section{„A képzelet sokkal fontosabb, mint a tudás. A tudás véges. A képzelet felöleli az egész világot.”}

\section{/Albert Einstein/}

\section{A 3D nyomtatás technológiája}

A 3D nyomtatók sokféleségének okai hasonlóak a 2D nyomtatók okaihoz. A következő hat pont a legmeghatározóbb, ha arról beszélünk, hogy milyen nyomtatási technológiára van szükség bizonyos tárgyak elkészítéséhez. Ezen tényezők: a nyomtató ára, a nyomtatási minőség, a nyomtatási sebesség, a nyomtató saját korlátai, melyik nyomtató felel meg a gyakorlatban a nyomtatásra, valamint mik a felhasználó elvárásai [8]. A tényezőket tekintve kell kiválasztani a megfelelö technológiát és annak megfelelően végezni a tárgy előállítását [7]. A gyártás folyamatának lépései -kisebb eltérésekkelmegegyeznek a különbözö technológiáknál (1. ábra):

- 3D modell megtervezése háromdimenziós tervező szoftverben,

- a modell elmentése valamely CAD formátumban (pl.: *.stl, *.step, *.iges),

- a modell betöltése egy 3D nyomtató szoftverbe (Cura, MakerBot Print, PrusaSlicer, Simplify3D),

- a szoftverbe illesztett háromdimenziós modell szeletelése a programban, 
- a program elmenti a nyomtatónak szükséges kódot és adathordozóra másolja, vagy közvetlenül továbbítja a nyomtatónak,

- a nyomtató beolvassa a kódot és elkezdi a tárgy szintenkénti kinyomtatását,

- kész a nyomtatott tárgy.
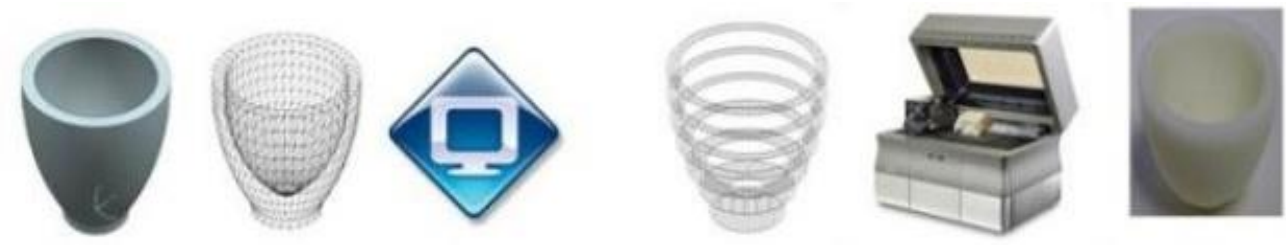

\section{1. ábra. A $3 D$ nyomtatás menete}

\subsection{Szálhúzásos, extrudálásos nyomtatás}

A szálhúzásos nyomtatás az egyik legelterjedtebb nyomtatási forma, mert a gépek árban megfizethetők és a nyomtatáshoz szükséges szoftverek is könnyen elérhetők bárki számára, emellett a nyomtató anyagok is könnyen beszerezhetök és gazdaságosak. Az FDM nyomtatást a Stratasys Ltd. vezette be az 1980-as években, miután Scott Crump kifejlesztette az eljárást. Legtöbb esetben hőre lágyuló polimer a nyomtatóanyag. A technológiával funkcionális, pontos prototípusokat, koncepcionális modelleket és gyártási alkatrészeket lehet előállítani. Mielőtt a gyártás megkezdődik, a felhasználónak szeletelnie kell a megtervezett 3D modelleket, hogy a nyomtató értelmezni tudja a parancsokat, ezután következik a fúvóka, valamint szükség esetén a tárgyasztal felfütése. Ezek után történik a szintenkénti nyomtatás. A gép extrudálja a megolvasztott filamentet, ami az asztalon kezd el szinteződni. Fontos a jó tapadás biztosítása a tárgyasztalon. Mint a többi technológiánál, itt is a tárgy méretén és bonyolultságán múlik a nyomtatás ideje. Az FDM eljárás utómunkálatai lehetnek a támaszanyagok eltávolítása, vagy homokszemcsés csiszolás, így lehet teljesen sima felületet adni a tárgyaknak. A BMW és a Nestlé gyáraiban is használják ezt az eljárást.

\section{Az Ender 5 nyomtató és nyomtatott tárgyak}

A 2. ábrán is látható Creality Ender-5 amellett, hogy egy pénztárca barát nyomtató sok értékes funkciót kapott. A nyomtató egy FDM technológia alapján müködő nyomtató, ami azt jelenti, hogy felhevíti, megolvasztja és extrudálja a különböző bevezetett filamentet. Extrudálás után a szinteket a tárgyasztalra rakja, így építi fel egymás után a rétegeket, ameddig el nem készül az egész objektum. A nyomtató tárgyasztala $220 \times 220$ x $300 \mathrm{~mm}$ méretü, így maximum ekkora tárgyak kinyomtatására alkalmas. Az Ender-5 ára 2019. júniusában 300 dollár volt, ami 90 ezer forint körüli árat jelent magyar viszonylatban. A Creality cég nagy figyelmet fordít a megfelelö, biztonságos csomagolásra, nagyon fontosnak tartja a vásárlói megelégedettséget. A nyomtatót használat előtt össze kellett rakni a használati utasítás szerinti szerelési útmutató alapján. Az összeállítás egyértelmü volt és körülbelül 1-1,5 órát vett igénybe. Az összerakás és a kapott nyomtatószál befüzése után már csak egy kalibrálás volt hátra használat előtt. A kalibrálás ebben a modellben még manuális, szemre kell a fúvóka magasságát beállítani az asztaltól. A sikeres kalibrálás után lehet próbanyomtatásokat indítani az elöre beprogramozott minták közül, vagy lehet saját modelleket feltölteni nyomtatásra. Tanácsos először próbakockákat nyomtatni a megfelelő nyomtatási paraméterek ellenőrzésére. A nyomtató egyik előnye, hogy ár-érték arányhoz viszonyítva nagy pontossággal tud nyomtatni, és viszonylag nagy nyomtató térrel rendelkezik. A nagy tárgyak nyomtatása azonban hosszabb időt vesz igénybe. A hosszú üzemeltetési idő kockázata, hogy 
az áramellátás kimaradhat, vagy bármilyen ok miatt le kell állítani a nyomtatást. Ezen problémák következményének elkerülése érdekében kapott a gép egy olyan funkciót, ami például váratlan áramkimaradás esetén képes visszaállítani a nyomtatás menetét az utolsó befejezett réteghez, így nem vész kárba az addig kinyomtatott tárgy. A nyomtatónak idáig egy gyengébb alkatrészével volt probléma, ez pedig a filament adagoló extruder volt. Pár hét nyomtatás után a müanyag alkatrész eltört és nem tudta elég erősen megfogni a nyomtatószálat, emiatt kevés anyag jutott el a fúvókához és az extruder nem adagolt elég anyagot a nyomtatáshoz. Az alkatrészt javasolt egy fém változatra vagy egy még fejlettebb, zárt dobozos megoldású extruderre cserélni, bármelyik alkatrész könnyen beszerezhető pár ezer forintos tétel. A nyomtató egység másik gyengesége a tárgyasztal, amely nincsen megfelelően megtámasztva és beremeg, ezért a hosszú tárgyak nyomtatása rosszabb minőségü lett, mint amilyet egy szilárdabb megtámasztás mellett tudna nyomtatni a nyomtató. Ez a probléma is kiküszöbölhető különböző támasztások felszerelésével. Ezen a pár apróságon kívül egy rendkívül jó ár-érték arányú hobby nyomtatóról beszélünk: egyszerü, felhasználóbarát kialakítása van, a vezérlő képernyő is egyszerüen kezelhető.

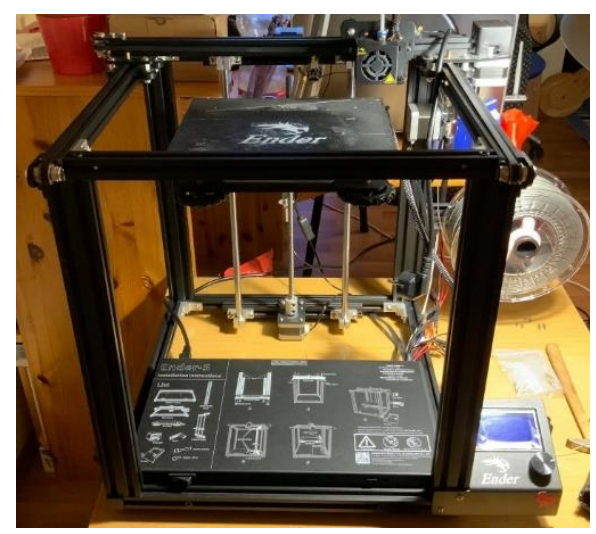

\section{2. ábra. Creality Ender 5}

A következő képeken néhány próba nyomtatás látható. Minden egyes nyomtatott darab egyedi, más és más nehézségek merültek fel a nyomtatás során. A kis fehér polip (3. ábra) egy különleges modell, amelynek az egész testét, karjait egyben tudja kinyomtatni a nyomtató, egymásba építi az alkatrészeket, így nincs szükség későbbi szerelésre. A kék csipesz (3. ábra), amit éppen nyomtatás közben lehet látni, a tekercsek tartójának rögzítésére szolgál, a fekete kisdoboz (4. ábra) pedig szivaccsal kitöltve filament tisztítására alkalmas. Ezen tárgyakból látszik, hogy a hobby nyomtatókkal lehetőség van olyan tárgyakat gyártani, amelyek segítségével a nyomtatások minősége javítható [5].

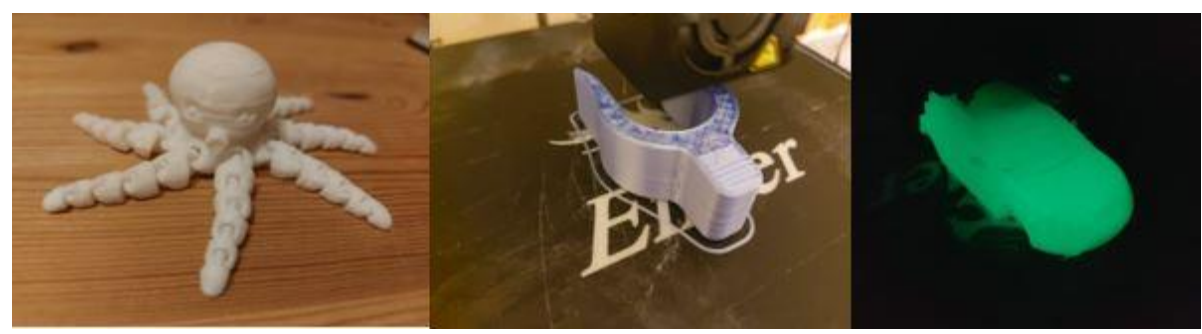

3. ábra. Nyomtatott használati és dísztárgyak 
A nyomtató anyagok között vannak különleges tulajdonsággal rendelkezök is, mint például hőmérsékletre színt váltó, vagy sötétben világító anyag: a 3. ábra ábrasorában a 3. képen látható, hogy éppen egy ilyen, sötétben világító autó nyomtatása történik. A 4. ábra szerinti képek közül az első egy együtt mozgó csavarpár modelljét, a második pedig egy bolygómủ modelljét szemlélteti. Egy-egy darab kinyomtatásával sok munka van, de az elvégzett munka során rendkívül sok ismeretre lehet szert tenni nem csak a technológiáról, de az így létrehozott modellek révén más tudományterületek is könnyebben megérthetővé válnak [6].

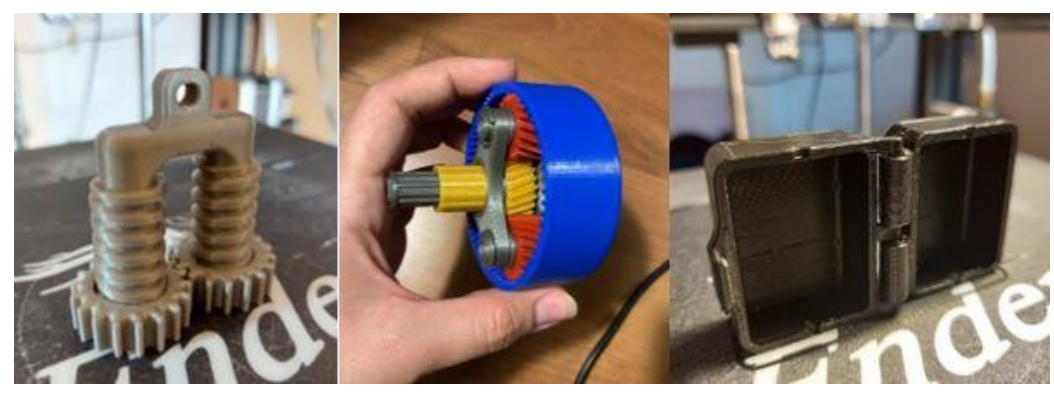

4. ábra. Nyomtatott és szerelt gépelemek

\section{Filament újrahasznosító gép koncepcionális tervezése}

Mint tervezö és hobby nyomtató mérnök azt kijelenthetem, hogy nincs olyan, hogy egyik nyomtatás közben sem születik selejt. Az amatőr nyomtatósok közül sokan otthon, egyedül tanulják meg a nyomtatás rejtelmeit, ezért is elkerülhetetlen, hogy hibázzanak. Nekünk, Miskolci Egyetemre járó diákoknak szerencsénk van, hogy diákkörök keretén belül segítséget kaphatunk a technológiával kapcsolatban, azonban nem mindenki ilyen szerencsés. Annak ellenére, hogy nekünk van segítségünk, mi is sokat hibázunk és rengeteget kell tanulnunk. A pazarlás csökkentésének a legjobb módja az, ha újra felhasználjuk a selejt nyomtatószálakat. Egy újrahasznosító gép legyártása is terheli a környezetet, azonban, ha az újrahasznosított filamentek mennyisége elég sok, akkor megéri a gépet legyártani és használni, ki fogja egyensúlyozni a hulladék okozta kárt, valamint csökkenteni fogja a filament vásárlást, ezzel együtt pedig a termékek gyártását is [2].

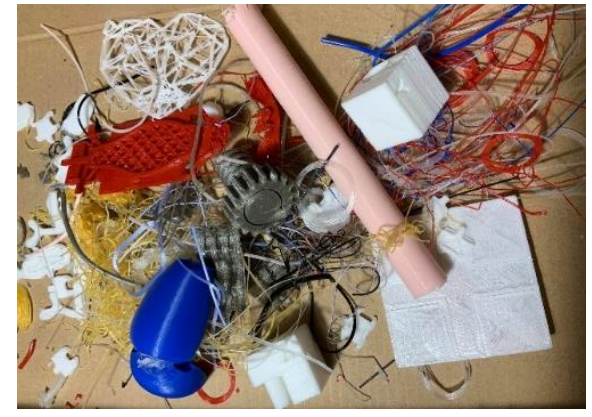

\section{5. ábra. Hulladék filament}

\subsection{Az újrahasznosító gép funkcionális részegységei}

A koncepcionális tervezés többféleképpen történhet. Szemléltetés szempontjából a funkcionális részegységek segítségével felépített ábrák egyszerübbé teszik a tervezett szerkezet müködésének ismerte- 
tését, ezért a megoldás ismertetése ezzel a módszerrel történt [4]. Az 1. táblázat összefoglalja azokat a funkcionális részegységeket, amelyek alapján a megoldásváltozatok megfogalmazásra kerültek.

1. táblázat. Funkcionális részegységek

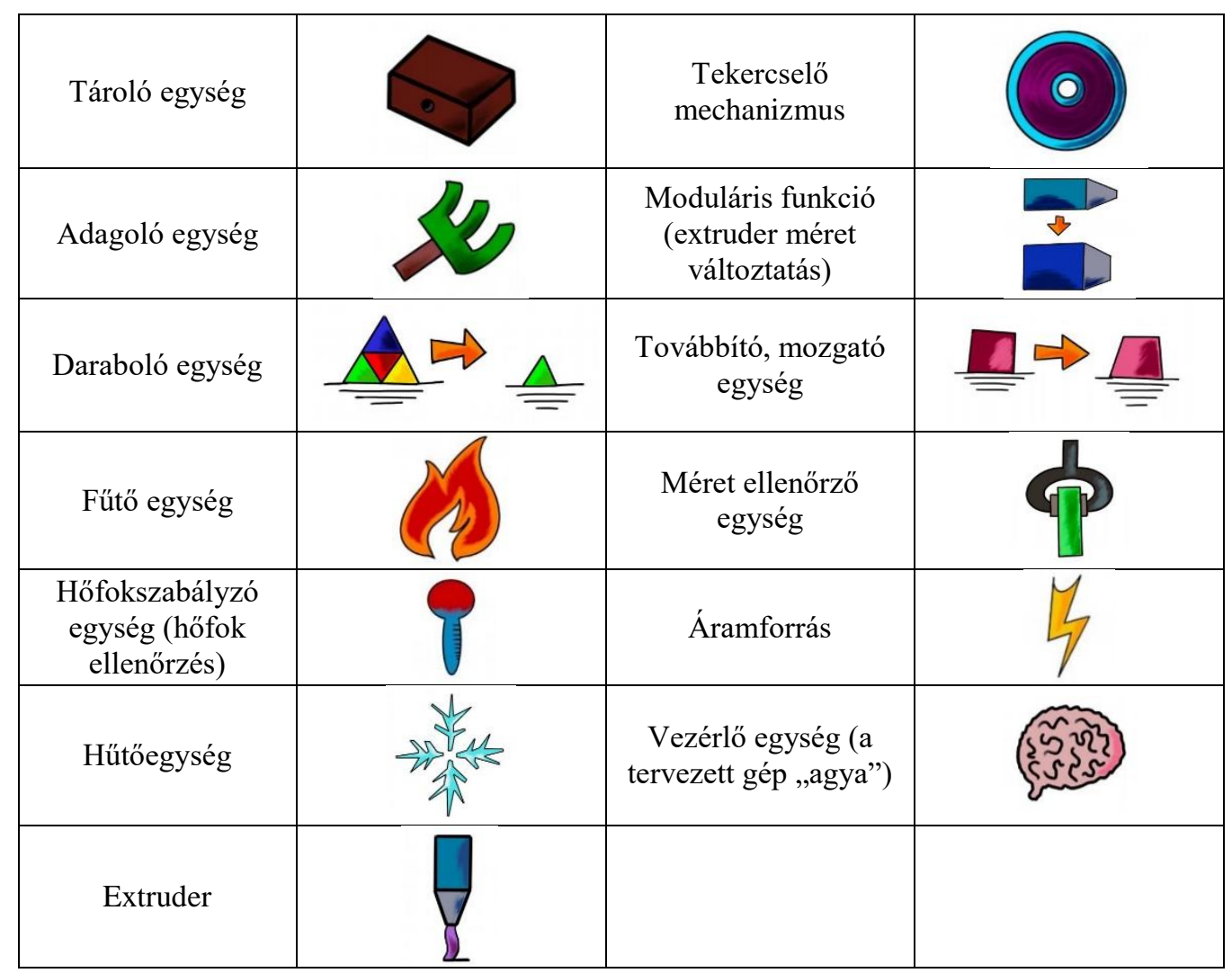

\subsection{Kidolgozott koncepció}

A feladatra több megoldásváltozat került definiálásra, melyek közül az optimális megoldásváltozat (6. ábra) funkcióban nagyon gazdag. A változat bonyolultsága egyben kompakt müködést is jelent, hiszen az egész rendszer a betöltéstől kezdődően automatikusan müködik. Az áramforrás és a vezérlés indítja el a folyamatokat egy mikrokontroller panel segítségével. A tárolóba helyezett müanyagokat szabályozott adagokban juttatja az adagoló egység a daraboló egységbe. A gép összedarabolja a filamentet az olvasztáshoz megfelelő méretüre. Az összeaprított müanyag darabokat továbbítja a mozgató egység a fütőegységhez, ahol megolvad az anyag. Az anyag megfelelő hőmérsékletéről a hőmérséklet szabályozó rendszer gondoskodik. Az olvadt anyag az extruderen keresztül távozik, ahol egyszerre megy keresztül méret ellenőrzésen és hütésen. A lehülést követően a gép összetekercseli az újrahasznosított filamentet és a belső terében tárolja. A megoldás speciális funkciója, hogy az extruder fej egy moduláris egység, mert kétféle méret cserélhető, a kívánt filament vastagságának megfelelően lehet 1,75 mm-es vagy $2,85 \mathrm{~mm}$-es. Ez a megoldás komplex, mégis egyszerü müködésü, mert minden automatikus. Látványtervét a 7 . ábra szerinti szabadkézi rajz szemlélteti. 


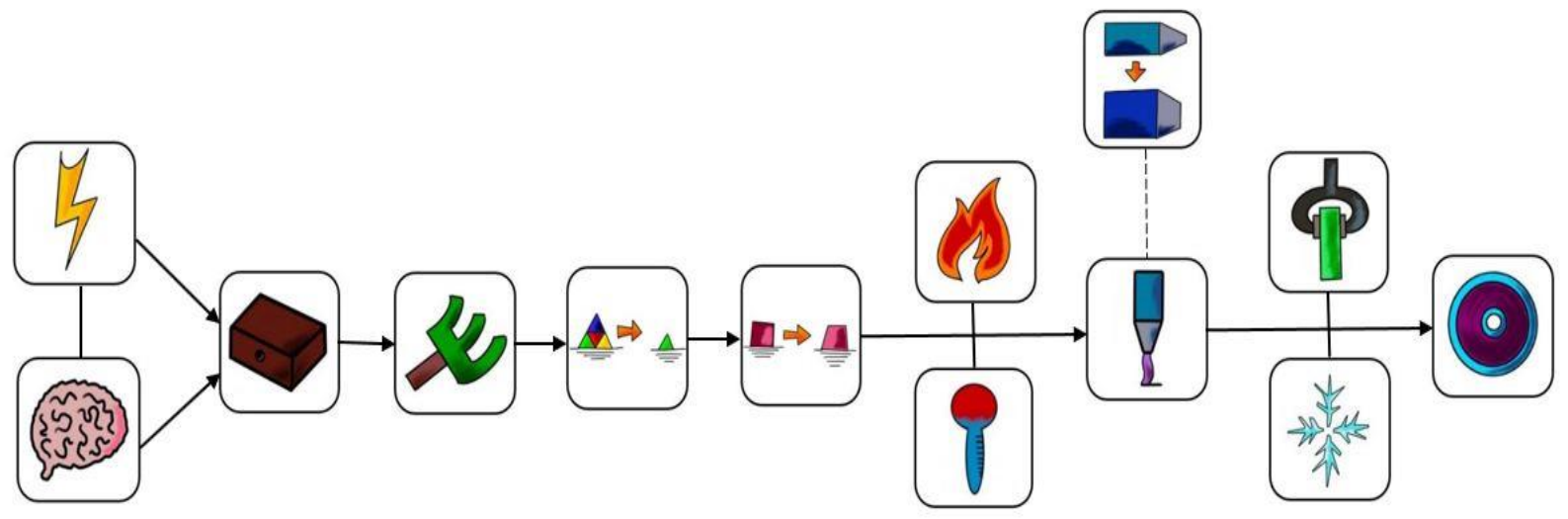

6. ábra. A kiválasztott megoldásváltozat

\section{5. Összefoglalás}

A tanulmány a 3D nyomtatás technológiájának megismerésére koncentrált. Ismertetésre került a technológiának a széles körben való elterjedése és sokoldalú felhasználhatósága. Ezután az extrudálásos technológia került bemutatásra, valamint a saját tulajdonú Creality Ender-5 nyomtató gépröl és az azzal nyomtatott tárgyakról volt szó. A filament újrahasznosító gépek iránti igény megállapítása után a munka hátralevő részében egy filament újrahasznosító berendezés koncepcionális tervezésére került sor. A távlati célok közt az újrahasznosító gép konstrukciós kidolgozása és lehetőség szerint megvalósítása is szerepel.

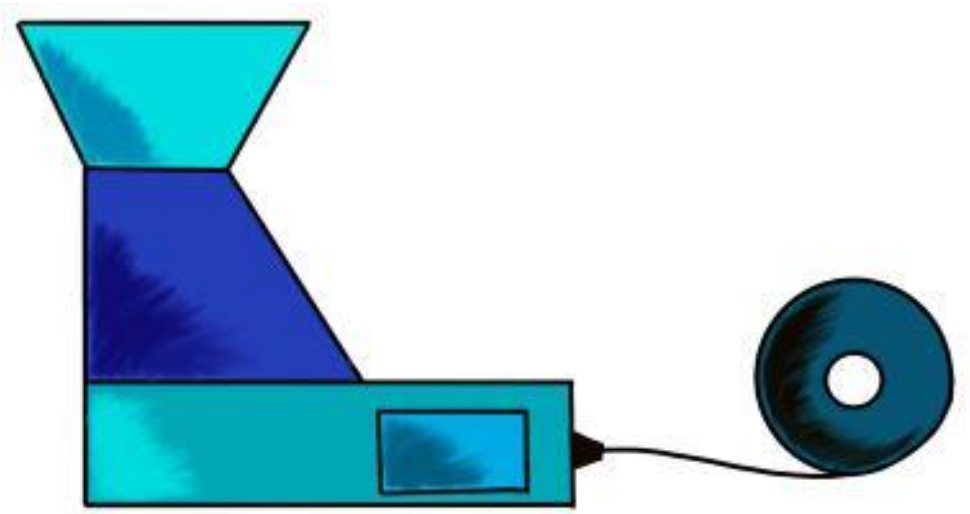

7. ábra. A filament újrahasznositó gép vázlata

\section{Köszönetnyilvánítás}

A cikkben ismertetett kutató munka az EFOP-3.6.1-16-2016-00011 jelü „Fiatalodó és Megújuló Egyetem - Innovatív Tudásváros - a Miskolci Egyetem intelligens szakosodást szolgáló intézményi fejlesztése" projekt részeként - a Széchenyi 2020 keretében - az Európai Unió támogatásával, az Európai Szociális Alap társfinanszírozásával valósul meg. 


\section{Irodalom}

[1] Kamondi, L., Takács, Á.: Környezettudatos tervezés - Útmutató és segédlet az elöadáshoz és a gyakorlathoz BSc. Szakos Ipari termék- és Formatervezö hallgatók részére, elektronikus jegyzet, készült a TÁMOP-4.2.1.B-10/2/KONV-2010-0001 jelü projekt részeként, frissítve a TÁMOP-4.2.4.A/2-11/1-2012-0001 jelü kiemelt projekt keretében az Európai Unió támogatásával, az Európai Szociális Alap társfinanszírozásával, Miskolc, 2014.

[2] Otto, K., Wood, K.: Product Design - Techniques in Reverse Engineering and New Product Development, ISBN 9780130212719, Prentice Hall, 2008.

[3] Jayatilleka, S., Okogbaa, G.: Accelerated Life Testing, 2014 Workshop on Accelerated Stress Testing and Reliability Conference, Saint Paul, Minnesota, Egyesült Államok, pp. 1-21.

[4] Takács, Á.: Számitógéppel segitett koncepcionális tervezési módszer, doktori (PhD disszertáció, Miskolc, 2010.

[5] Redwood, B., Schöffer, F., Garret, B.: The 3D printing handbook, ISBN 9789082748505, Hubs B. V., Amsterdam, 2017

[6] Morgan, B., Ross, S., Beatty, S.: 3D printing projects-Amazing ideas to design and make, ISBN 9781465464767, DK Publishing, New York, 2017

[7] Kumar, L.J., Pandey, P.M., Wimpenny, D.I.: $3 D$ printing and additive manufacturing technologies, ISBN 9789811303043, Springer Nature Singapore Pte Ltd., 2019. https://doi.org/10.1007/978-981-13-0305-0

[8] Kaziuna, F.A.: Make: 3D printing, ISBN 9781457182938, Maker Media, Canada, 2014. 